\title{
ELASTYCZNE FORMY ZATRUDNIENIA I ZAKRES ICH WYSTĘPOWANIA
}

\author{
Andrzej Brzeziński \\ Politechnika Częstochowska \\ Wydział Zarządzania
}

\begin{abstract}
Streszczenie: Artykuł podejmuje problematykę elastycznych form zatrudnienia, rozpoczynając od prezentacji aktualnie występujących w polskim prawie. Poprzez ich porównanie wskazano na zalety i wady z punktu widzenia pracowników. Badania przeprowadzone wśród pracowników pokazują zasięg występowania elastycznych form, wśród których dominuje umowa-zlecenie.
\end{abstract}

Słowa kluczowe: pracodawca, interesariusz, zasoby ludzkie, elastyczne formy zatrudnienia

DOI: $10.17512 /$ znpcz.2017.4.1.15

\section{Wprowadzenie}

Turbulentność otoczenia wymusza na przedsiębiorstwach ciągłe dopasowywanie do zmieniających się warunków zewnętrznych. Owe dopasowania dotyczą zachowań rynkowych oraz wnętrza przedsiębiorstw z wielkością zasobów na czele, co oznacza potrzebę ich zwiększania w okresie koniunktury gospodarczej czy sezonu i zmniejszania w okresach dekoniunktury i pozasezonowych. Wiąże się to również z zasobami ludzkimi, gdzie poza sprawnością działania personelu jego wielkość jest również istotna. Specyfika tych zasobów, w połączeniu z uwarunkowaniami prawnymi, czyni zarówno proces doboru pracowników, jak i ich zwalnianie (czynniki decydujące o poziomie zatrudnienia) znacznie trudniejszymi do przeprowadzenia niż zmiany wielkości pozostałych zasobów przedsiębiorstwa. Tradycyjny model zatrudnienia $z$ umowami o pracę jest więc poszerzany o inne formy powierzenia pracy, składające się z umów cywilnoprawnych bazujących na Kodeksie cywilnym i samozatrudnienia, czyli świadczenia usług $\mathrm{w}$ ramach prowadzonej działalności gospodarczej, co pozwala na większą elastyczność w postaci dopasowania wielkości personelu do bieżących potrzeb. Te formy zatrudnienia, określane jako elastyczne czy nietypowe, mają dość szerokie zastosowanie w polskich przedsiębiorstwach, choć nie jest to poziom podobny do spotykanego w USA, gdzie w 2015 roku było to aż 34\% wszystkich zatrudnionych i udział ten rośnie (Trendy HR 2015). Poza elastycznością w kształtowaniu wielości personelu umowy te charakteryzują się innymi korzyściami dla przedsiębiorców, gdzie niższe koszty pracy i możliwości ich szybkiego obniżenia $\mathrm{w}$ pogarszających się warunkach zewnętrznych czy spadku kondycji ekonomicznej firmy należą do głównych zalet. W przeciwieństwie do umów o pracę te formy zatrudnienia dają pracodawcy większe możliwości dostosowania charakteru kontraktu do potrzeb w zakresie długości 
trwania zatrudnienia, czasu pracy, miejsca wykonywania pracy i większej swobody przy ich rozwiązywaniu.

Ludzie zatrudniani w ten sposób mogą zaś przystawać na takie warunki, gdyż oferujący pracę nie dopuszczają innych wyborów. Może też być tak, że praca jest przejściowa, w poszukiwaniu wymarzonego etatu czy pracodawcy, albo dorywcza, jaką podejmują kobiety wychowujące dzieci oraz studenci, którzy muszą godzić podejmowane obowiązki pracownicze ze studiowaniem. Zajęcia dydaktyczne dają ograniczone możliwości podjęcia pracy na pełny etat ze ściśle określonym czasem pracy. Ograniczone uprawnienia pracownicze związane $z$ tymi umowami są rekompensowane większą swobodą przy luźnych więzach z pracodawcą, pozwalających godzić życie zawodowe z życiem prywatnym, co jest charakterystyczne dla pokolenia Y i Z.

Celem artykułu jest przegląd elastycznych form zatrudnienia, które aktualnie dopuszczają obowiązujące regulacje prawne, ze wskazaniem czynników rozwoju tych form oraz ich wad i zalet. Przeprowadzone badania wśród pracowników mają pokazać zasięg ich występowania oraz rozkład poszczególnych form w badanej próbie.

\section{Elastyczne formy zatrudnienia - uwarunkowania rozwoju}

Elastyczność zatrudnienia to zdolność dostosowania liczby pracujących do aktualnych potrzeb przedsiębiorstwa, które wiążą się z: koniunkturą gospodarczą, rentownością, wynagrodzeniami czy wydajnością pracy (Kryńska 2007, s. 1). Jest to możliwość wpływu na wielkość zasobów ludzkich. Optymalizacja poziomu zatrudnienia, w odpowiedzi na bieżące potrzeby i możliwości przedsiębiorstwa, jak się wydaje, może być głównym argumentem sięgania po tego typu rozwiązania w zatrudnianiu ludzi. Wynika to z braku występowania obowiązkowych okresów wypowiedzeń czy okresów ochronnych dla zwolnień (kobiety w ciąży, okres choroby, pracownicy $\mathrm{w}$ wieku przedemerytalnym), ale także ściśle określony czas pracy (odpoczynku), który nie może być przekroczony. Równie ważny jest także czynnik ekonomiczny w postaci niższych kosztów pracy, które wiążą się z kosztami przywilejów pracowniczych występujących w przypadku umów o pracę, przede wszystkim na czas nieokreślony. Są to świadczenia na rzecz pracownika w postaci: urlopu, zasiłku chorobowego czy odpraw (emerytalna, rentowa, pośmiertna). Poza tym pracodawca jest zobowiązany do zapewnienia bezpiecznych i higienicznych warunków pracy, a koszty z tym związane powinny być w pełni przez niego pokryte.

Kodeks pracy (dział trzeci) ściśle określa warunki wynagradzania pracowników dotyczące: terminu, formy i zasad (układ zbiorowy pracy lub regulamin wynagrodzeń) oraz dodatków za pracę: w godzinach nadliczbowych, w niedziele i święta. Co najważniejsze, praca musi być zawsze wynagradzana, a jej minimalna wysokość ( 2000 zł brutto w 2017 roku) nie może być w żaden sposób obniżona (Rozporządzenie Rady Ministrów z dnia 9 września 2016 r. ...). W dodatku pracownikowi przysługują uprawnienia rodzicielskie (urlopy, zasiłki), które gwarantuje dział ósmy $K o$ deksu pracy. 
Wedhug B. Skowron-Mielnik (Skowron-Mielnik, Wojtkowiak 2016, s. 82-83) motywy i zakres występowania elastyczności zatrudnienia z punktu widzenia pracodawcy wiążą się z:

- możliwością rezygnacji z pracownika w sytuacji obniżonego zapotrzebowania na pracę (niezależnie od elastyczności czasu pracy, np. w ramach wydłużonego okresu rozliczenia), wraz z jednoczesnym zapewnieniem możliwości pozyskania pracownika w przypadku ponownego wzrostu;

- ograniczaniem kosztów pracy ponoszonych przez pracodawcę w relacji do motywacji pracownika i wartości, jaką otrzymuje (wynagrodzenie netto).

Do instrumentów, które zapewniają elastyczność zatrudnienia, zalicza się przede wszystkim (Skowron-Mielnik, Wojtkowiak, s. 84):

- korzystanie z umów terminowych,

- kontraktowanie pracy,

- korzystanie z umów cywilnoprawnych,

- wynajem pracowników tymczasowych za pośrednictwem agencji pracy tymczasowej,

- wykorzystywanie umów o współpracy z osobami prowadzącymi działalność gospodarczą (samozatrudnienie), realizowanych w praktyce na zasadach pracy zgodnie z jej charakterem określonym w Kodeksie pracy, przy zapewnieniu formalnego stosunku cywilnoprawnego, opartego na Kodeksie cywilnym.

Czynniki, które mają również wpływ na wybór przez pracodawców nietypowych form zatrudnienia, to (IPiSS 2007, s. 60):

- wiedza o możliwości elastycznej organizacji pracy i uwarunkowaniach prawnych ich stosowania;

- wiedza o wadach i zaletach elastycznych form dla przedsiębiorstwa oraz:

- osób stanowiących elastyczny personel,

- dla pozostałych pracowników,

- dla menedżerów zarządzających elastycznymi pracownikami;

- dobrowolność pracy w elastycznej formie (wybór - nie przymus) Inne powody rozwoju to (Czapulis-Rutkowska 2003, s. 89-91):

- odchodzenie od tradycyjnego modelu rodziny, w którym to mężczyzna jest jedynym jej żywicielem, skutkujące aktywizacją kobiet na rynku pracy i większym zainteresowaniem pracą w niepełnym wymiarze czasu;

- przyczyny technologiczne;

- niektóre rodzaje prac (prace wykonywane przez doradców podatkowych i prawnych czy biegłych rewidentów) powinny być raczej przedmiotem umów cywilnoprawnych niż umowy o pracę;

- równowaga praca-życie, podejmowanie prac przez osoby studiujące, które muszą łączyć obowiązki pracownika i studenta;

- wydłużenie trwania życia pracownika i podejmowanie pracy w okresie emerytalnym.

Na rozwój elastycznego zatrudnienia mają również wpływ korzyści dla pracowników, takie jak (IPiSS 2007, s. 61): 
- większe szanse znalezienia odpowiedniej pracy;

- lepsze warunki godzenia pracy zawodowej z życiem prywatnym (rodzinnym);

- eliminacja stresu związanego ze zdarzeniami losowymi w życiu prywatnym (np. choroba dziecka);

- większe możliwości rozwoju zawodowego (więcej czasu na doskonalenie: studia, kursy itp.);

- zmniejszenie zagrożenia utratą pracy (możliwość zmniejszenia wymiaru godzin), którego nie ma przy umowach o pracę.

Korzystanie przez pracodawców z elastycznych form może rosnąć w przyszłości, gdyż struktura przyszłościowego modelu zatrudnienia w przedsiębiorstwach wydaje się ewoluować w kierunku istnienia stosunkowo niewielkiej grupy stałych pracowników, stanowiących rdzeń personelu, i głównej grupy pracowników zasobowych i peryferyjnych (Sekuła 2001, s. 68). Stała grupa to kierownictwo przedsiębiorstwa i pracownicy istotni dla funkcjonowania przedsiębiorstwa zatrudnieni na umowach o pracę na czas nieokreślony, zaś w przypadku pozostałych zatrudnionych, zwłaszcza pracowników peryferyjnych, przewiduje się elastyczne formy zatrudnienia.

\section{Przegląd elastycznych form zatrudnienia}

Elastyczne formy zatrudnienia występują już wśród umów o pracę i mają miejsce wtedy, gdy zostanie naruszony jeden $\mathrm{z}$ warunków tradycyjnego modelu zatrudnienia (Bąk 2009, s. 9-10):

- rodzaj umowy o pracę - umowa na czas nieokreślony,

- wymiar czasu pracy - pełny etat,

- miejsce zatrudnienia - siedziba pracodawcy,

- regulamin zatrudnienia - praca w wyznaczonych i stałych godzinach,

- długość okresu zatrudnienia - długoletnie i nieprzerwane zatrudnienie.

Takie elastyczne formy, nazywane pracowniczymi, występują najczęściej w postaci (Bąk 2009, s. 27):

1) umów terminowych (temporary employment),

2) zatrudnienia w niepełnym wymiarze czasu pracy (part time).

Cechą umów terminowych jest określenie, już w momencie ich zawierania, daty ich zakończenia, co może nastąpić na trzy sposoby (Bąk 2009, s. 28):

- za pomocą określenia czasu trwania umowy,

- poprzez podanie daty kalendarzowej zakończenia umowy,

- poprzez wskazanie zdarzenia, którego data jest znana (np. do powrotu nieobecnego pracownika).

Niepełny wymiar zatrudnienia to odchylenia od pełnego wymiaru czasu pracy, który zwykle oznacza równy ustawowym normom czas pracy (na mocy postanowień układu zbiorowego pracy może być zmniejszony). Ustalając wymiar czasu pracy dla pracownika niepełnoetatowego, należy odnieść się do wymiaru czasu pracy określonego dla zatrudnionych w pełnym wymiarze. Może to być skrócenie przeciętnej normy tygodniowej normy dobowej. Uprawnienia pracownicze w swo- 
im wymiarze są proporcjonalne do czasu pracy i np. urlopy powinny być wykorzystywane w dni wyznaczone jako dni pracujące pracownika. Forma daje możliwość łączenia obowiązków zawodowych $\mathrm{z}$ obowiązkami życia prywatnego, np. obowiązkami rodzicielskimi, studenckimi czy z uprawianiem sportu. Dla pracodawcy to możliwość elastycznego reagowania na płynące sygnały z rynku, stąd jej częste stosowanie. Według danych Eurostatu w krajach gospodarczo rozwiniętych to poziom 18-25\%, a w Holandii nawet 40\%, zaś w Polsce to ok. 10-procentowy udział wśród wszystkich form zatrudnienia.

Ze względów ograniczeń objętościowych artykułu analizowane będą tylko formy zatrudnienia niepracowniczego oraz kontrakt menedżerski z uwagi na jego szerokie zastosowanie. Elastyczne formy zatrudnienia niepracowniczego, dzielą się na (Bąk 2009, s. 11):

- umowy cywilnoprawne,

- samozatrudnienie.

Na umowy cywilnoprawne składają się:

- umowa-zlecenie,

- umowa o dzieło,

- umowa agencyjna.

Według Kodeksu cywilnego przez umowę-zlecenie przyjmujący zlecenie (zleceniobiorca) zobowiązuje się do dokonania określonej czynności prawnej dla dającego zlecenie (zleceniodawcy) (Kodeks cywilny, art. 734 § 1). Czynność prawna to czyn (ludzkie zachowanie), w którym norma prawna wiąże określone konsekwencje (np. sprzedaż). Przedmiotem umowy jest wykonanie czynności z należytą starannością, ale zleceniobiorca nie ponosi odpowiedzialności za nieosiągnięcie pożądanego przez zleceniodawcę rezultatu . Pomiędzy stronami, którymi mogą być osoby fizyczne (prowadzące lub nieprowadzące działalności gospodarczej) oraz osoby prawne prowadzące działalność gospodarczą, nie powstają zależności służbowe. Nie ma tu więc stosunku podporządkowania ani trwałego związku (ciągłości) (Gersdorf 1993, s. 71). Zlecenie jest umową konsensualną, dwustronnie zobowiązującą, odpłatną lub nieodpłatną, ale w tym drugim przypadku wymagany jest odpowiedni zapis. Zleceniobiorca $\mathrm{w}$ trakcie wykonywania zlecenia jest zobowiązany do bieżącego kontaktowania się ze zleceniodawcą, co daje zleceniodawcy możliwość bieżącej kontroli i uniknięcia popełnienia błędów w trakcie pracy (Kodeks cywilny, art. 740). Obligatoryjnie zleceniobiorca jest zobowiązany zdać sprawozdanie z wykonania zlecenia, po jego zakończeniu. Strony umowy mają możliwość jej wypowiedzenia (Kodeks cywilny, art. 746). Zleceniodawca, wypowiadając zlecenie, jest zobowiązany do pokrycia wszelkich wydatków poniesionych przez zleceniobiorcę, które poniósł w celu starannego wykonania zlecenia, oraz części wynagrodzenia należnego za wykonaną pracę. Zleceniobiorca, który ma prawo wypowiedzieć umowę w każdym czasie, jest odpowiedzialny za powstanie szkody.

Umowa o dzieło jest także umową nazwaną, na podstawie której przyjmujący zamówienie zobowiązuje się do wykonania oznaczonego dzieła, a zamawiający do zapłaty wynagrodzenia za to dzieło i jego odbioru (Kodeks cywilny, art. 627). Umowa jest więc umową odpłatną, dwustronnie zobowiązującą, wzajemną i kon- 
sensualną (Bąk 2009, s. 77). Zwana jest także umową rezultatu, gdzie wykonawca ma obowiązek osiągnięcia określonego wyniku i tylko za to zapłaci zamawiający. $\mathrm{W}$ przeciwieństwie do umowy-zlecenia nie ma tu znaczenia, jakie wysiłki podejmował wykonawca $\mathrm{w}$ trakcie realizacji, a liczy się tylko efekt końcowy, który musi być przyjętym w umowie dziełem. Dzieło zaś może mieć charakter materialny (napisanie książki), ale może też występować w niematerialnej postaci (organizacja eventu), co odróżnia tę umowę od zlecenia i od innych podobnych stosunków zobowiązaniowych. Wykonanie dzieła oznacza jego stworzenie bądź przetworzenie. Umowa jest zawierana w podobny sposób jak umowa-zlecenie i do jej ważności konieczne są zgodne oświadczenia woli stron. Nie jest tu wymagana wyłącznie forma pisemna, choć celowe jest jej zawarcie w formie pisemnej, zwłaszcza dla szczegółowego określenia dzieła. Może być zawarta $\mathrm{z}$ własnym pracownikiem, a także ze zleceniobiorcą (Grzonka 2013, s. 60). Poza sprecyzowaniem w umowie dzieła istotne jest również określenie terminu jego odbioru.

Umowa agencyjna jest cywilnoprawną umową obrotu profesjonalnego, w której stronami są wyłącznie przedsiębiorcy, stosujący zasadę lojalności (Drela 2011, s. 241). Przez umowę agencyjną przyjmujący zlecenie (agent) zobowiązuje się w ramach działalności swego przedsiębiorstwa do stałego pośredniczenia, za wynagrodzeniem, przy zawieraniu z klientami umów na rzecz dającego zlecenie przedsiębiorcy albo do ich zawierania w jego imieniu (Kodeks cywilny, art. $758 \S 1$ ). Przedmiotem umowy może być pośrednictwo lub przedstawicielstwo (Grzonka 2013, s. 81). Pośrednictwo oznacza stałe wykonywanie różnego rodzaju czynności (wyszukanie klientów, prezentacja oferty itp.), które zmierzają do zawarcia przez zleceniodawcę umowy z klientem. Przedstawicielstwo to posunięta dalej forma, która oznacza zawieranie umów na rzecz i w imieniu zleceniodawcy. Umowa agencyjna jest konsensualna, wzajemna i odpłatna. Ważną cechą tej umowy, w odróżnieniu od zlecenia, jest stałość świadczenia usług przez agenta na rzecz zlecającego, rozumiana jako wielokrotność i powtarzalność czynności, do których świadczenia musi on posiadać pełnomocnictwo. Umowa zawierana jest w oparciu o zasadę lojalności i wzajemnego zaufania. Agent za świadczone usługi otrzymuje zwykle prowizję, której wysokość zależy od efektów jego działań na rzecz zleceniodawcy (Kodeks cywilny, art. 758). Umowa powinna mieć formę pisemną, a w odróżnieniu od umowy o pracę brak jest podległości służbowej agenta kierownictwu podmiotu zlecającego, ale powinien stosować się do jego wskazówek.

Samozatrudnieniem określa się pracę na własny rachunek, świadczoną dla jednego lub głównie jednego przedsiębiorcy, w ramach prowadzonej działalności gospodarczej. Na gruncie prawnym samozatrudnienie jest to jednoosobowa działalność gospodarcza, wykonywana samodzielnie przez przedsiębiorcę, kiedy nie zatrudnia się żadnych osób. Jako forma zatrudnienia jest podobna do umowy agencyjnej, czyli jest to związek dwóch stron, będących przedsiębiorcami.

Szczególną formą zatrudnienia jest kontrakt menedżerski (umowa nienazwana w polskim prawodawstwie). Forma ta występuje w trzech postaciach: umowy o pracę, umowy o świadczenie usług lub tzw. umowy o współpracy. W pierwszym przypadku jest to umowa $\mathrm{z}$ regulacjami prawa pracy $\mathrm{z}$ osobą, która będzie pełniła funkcje kierownicze. Jest to więc umowa o pracę, która została nazwana przez 
strony kontraktem menedżerskim, a menedżer jest pracownikiem $\mathrm{z}$ wszelkimi uprawnieniami pracowniczymi (Kodeks pracy, art. $22 \S 1$ ). Ostateczna kwalifikacja kontraktu do umów o pracę lub do form niepracowniczych zależy od okoliczności konkretnego przypadku (Wyrok SN 2005). Kontrakt jako umowa cywilnoprawna jest specyficzną formą zatrudnienia kadry menedżerskiej, w której menedżer zobowiązuje się do samodzielnego prowadzenia przedsiębiorstwa (lub jego oddziału) drugiej strony, na jej rachunek i ryzyko, przy czym kierowanie to jest we własnym lub cudzym imieniu. Zakres zadań menedżera jest tu dowolny, a czas i miejsce pracy menedżera określają strony w oparciu o czynności, jakie stanowią nakreślone obowiązki. Kontrakt jest więc regulowany przepisami o zleceniu. Podobna swoboda występuje przy określaniu wynagrodzenia, które zwykle składa się z części stałej, powiększanej o premie, których wielkość uzależniona jest od efektów kierowania. Istotnym jest, że kontrakt menedżerski może być nieodpłatny, co jest ważne w przypadku zarządzających właścicieli małych firm, ze słabą kondycją finansową zwłaszcza w fazach startu, dla których korzyściami jest wzrost firmy i przyszły zysk.

Należy dodać, że wśród elastycznych form znane są jeszcze m.in. (Bąk 2009, s. 27): job-sharing, work-sparing, zatrudnienie rotacyjne (job-rotation), praca nakładcza, telepraca czy praca na wezwania, które ze względu na ograniczenia objętościowe publikacji nie będą tu omawiane (zob.: Gableta 2013, s. 120-122).

W Tabeli 1 zestawiono najbardziej popularne formy zatrudnienia ze wskazaniem ich charakterystycznych cech, z których wynikają określone zalety i wady dla pracowników.

Poza wymienionymi, do korzyści pracowniczych należą jeszcze: urlopy macierzyńskie i wychowawcze, ochrona w okresie choroby czy ciąży kobiet. Ochroną objęte są również wynagrodzenia pracownicze, pod względem terminu ich wypłaty, minimalnej kwoty i niemożliwości rezygnacji przez pracownika (Kodeks pracy, art. 87-88). W przypadku zwolnień grupowych pracownicy w przeciwieństwie do pozostałych form otrzymają odprawy (Skowron-Mielnik, Wojtkowiak 2016, s. 81-84). Prowadzone badania pokazują, że warunki pracy, w jakich funkcjonują pracownicy, w większym stopniu spełniają wymogi pod względem bezpieczeństwa i higieny pracy (Brzeziński 2016, s. 358; Żaczkiewicz-Zborska, Marczuk 2008). 
Tabela 1. Porównanie form zatrudnienia - stan po 1 stycznia 2017 r.

\begin{tabular}{|c|c|c|c|c|}
\hline $\begin{array}{l}\text { Zatrudnienie } \\
\text { na podstawie }\end{array}$ & \multicolumn{4}{|c|}{ Umowy cywilnoprawne } \\
\hline Umowa o pracę & Umowa-zlecenie & Umowa o dzielo & Samozatrudnienie & $\begin{array}{c}\text { Kontrakt } \\
\text { menedżerski }\end{array}$ \\
\hline $\begin{array}{l}\text { Stronami umowy są: } \\
\text { pracodawca } \\
\text { i pracownik. }\end{array}$ & $\begin{array}{l}\text { Stronami umowy są: } \\
\text { zleceniodawca } \\
\text { i zleceniobiorca. }\end{array}$ & $\begin{array}{l}\text { Stronami umowy są: } \\
\text { zlecający } \\
\text { i wykonawca. }\end{array}$ & $\begin{array}{l}\text { Stronami umowy są: } \\
\text { przedsiębiorca- } \\
\text {-zlecający } \\
\text { i przedsiębiorca- } \\
\text {-wykonawca. }\end{array}$ & $\begin{array}{l}\text { Stronami umowy są: } \\
\text { przedsiębiorca } \\
\text { i zarządzający (osoba } \\
\text { fizyczna lub } \\
\text { przedsiębiorca). }\end{array}$ \\
\hline $\begin{array}{l}\text { Umowę reguluje } \\
\text { Kodeks pracy, } \\
\text { a roszczenia dochodzi } \\
\text { się przed sądem pracy } \\
\text { przed upływem } 3 \text { lat. }\end{array}$ & $\begin{array}{l}\text { Zlecenie reguluje } \\
\text { Kodeks cywilny, } \\
\text { a roszczenia dochodzi } \\
\text { się przed sądem } \\
\text { cywilnym przed } \\
\text { upływem } 2 \text { lat. }\end{array}$ & $\begin{array}{l}\text { Umowę reguluje } \\
\text { Kodeks cywilny, } \\
\text { a roszczenia dochodzi } \\
\text { się przed sądem } \\
\text { cywilnym przed } \\
\text { upływem } 2 \text { lat. }\end{array}$ & $\begin{array}{l}\text { Jest umową nienazwa- } \\
\text { ną, a roszczenia do- } \\
\text { chodzi się przed sądem } \\
\text { cywilnym przed } \\
\text { upływem } 2 \text { lat. }\end{array}$ & $\begin{array}{l}\text { Jest umową nienazwa- } \\
\text { ną, a roszczenia } \\
\text { dochodzi się przed } \\
\text { sądem cywilnym przed } \\
\text { upływem } 10 \text { lat dla } \\
\text { świadczeń jednorazo- } \\
\text { wych i } 3 \text { lat dla świad- } \\
\text { czeń okresowych. }\end{array}$ \\
\hline $\begin{array}{l}\text { Pracownik jest dobro- } \\
\text { wolnie } \\
\text { podporządkowany } \\
\text { pracodawcy, który } \\
\text { może mu wydawać } \\
\text { polecenia. }\end{array}$ & $\begin{array}{l}\text { Zleceniodawca może } \\
\text { jedynie wydawać } \\
\text { wskazówki odnośnie } \\
\text { świadczonej usługi. }\end{array}$ & $\begin{array}{l}\text { Wykonawca ma dużą } \\
\text { swobodę wykonywa- } \\
\text { nia dzieła. Zamawiają- } \\
\text { cy ma prawo do } \\
\text { kontroli sposobu } \\
\text { (zmian) wykonywania } \\
\text { dzieła oraz odstappienia } \\
\text { od umowy, jeśli dzieło } \\
\text { nie zostanie wykonane } \\
\text { lub jest wadliwe. }\end{array}$ & $\begin{array}{l}\text { Wykonawca ma } \\
\text { zwykle swobodę } \\
\text { wykonania usługi. }\end{array}$ & $\begin{array}{l}\text { Menedżer ma dużą } \\
\text { swobodę działania. Nie } \\
\text { jest podporządkowany } \\
\text { bieżącym poleceniom } \\
\text { właściciela. Nie można } \\
\text { mu powierzyć dodat- } \\
\text { kowych zadań. }\end{array}$ \\
\hline $\begin{array}{l}\text { Pracownik musi } \\
\text { świadczyć swoją pracę } \\
\text { osobiście. }\end{array}$ & $\begin{array}{l}\text { Zleceniobiorca powi- } \\
\text { nien wykonywać } \\
\text { zlecenie osobiście, ale } \\
\text { może wskazać zastęp- } \\
\text { cę, za zgodą zlecenio- } \\
\text { dawcy. }\end{array}$ & $\begin{array}{l}\text { Wykonawca może, } \\
\text { choć nie musi wyko- } \\
\text { nywać swojej pracy } \\
\text { osobiście. }\end{array}$ & $\begin{array}{l}\text { Wykonawca nie musi } \\
\text { wykonywać swojej } \\
\text { pracy osobiście, chyba } \\
\text { że jest taki zapis } \\
\text { w umowie. }\end{array}$ & $\begin{array}{l}\text { W kontrakcie można } \\
\text { przewidzieć } \\
\text { zastępstwo menedżera. }\end{array}$ \\
\hline $\begin{array}{l}\text { Pracownik musi } \\
\text { otrzymać } \\
\text { wynagrodzenie za } \\
\text { pracę w minimalnej } \\
\text { wysokości } 2000 \mathrm{zł} \\
\text { brutto (pełny etat). } \\
\end{array}$ & $\begin{array}{l}\text { Zlecenie może być } \\
\text { niepłatne lub płatne, } \\
\text { z minimalnym } \\
\text { wynagrodzeniem } \\
\text { brutto } 13 \text { zł za godz. } \\
\text { świadczonych usług. } \\
\end{array}$ & $\begin{array}{l}\text { Umowa o dzieło może } \\
\text { być wyłącznie płatna. } \\
\text { Wynagrodzenie } \\
\text { następuje za wykona- } \\
\text { nie oznaczonego } \\
\text { dzieła. }\end{array}$ & \begin{tabular}{|l|} 
Wynagrodzenie jest \\
zwykle prowizyjne, ale \\
powinno wynosić co \\
najmniej 13 zł/godz. \\
brutto za świadczone \\
usługi.
\end{tabular} & $\begin{array}{l}\text { Menedżer otrzymuje } \\
\text { wynagrodzenie } \\
\text { w wysokości ustalonej } \\
\text { w kontrakcie, ale może } \\
\text { też świadczyć usługę za } \\
\text { darmo. }\end{array}$ \\
\hline $\begin{array}{l}\text { Umowa musi być } \\
\text { zawarta pisemnie nie } \\
\text { później niż w dniu } \\
\text { rozpoczęcia pracy. }\end{array}$ & $\begin{array}{l}\text { Zlecenie może być } \\
\text { w dowolnej formie: } \\
\text { ustnej, pisemnej } \\
\text { lub w sposób } \\
\text { dorozumiany. }\end{array}$ & $\begin{array}{l}\text { Umowa może być } \\
\text { w dowolnej formie: } \\
\text { ustnej, pisemnej lub } \\
\text { w sposób } \\
\text { dorozumiany. }\end{array}$ & $\begin{array}{l}\text { Umowa może być } \\
\text { w dowolnej formie: } \\
\text { ustnej, pisemnej lub } \\
\text { w sposób } \\
\text { dorozumiany. }\end{array}$ & $\begin{array}{l}\text { Kontrakt menedżerski } \\
\text { powinien być sporzą- } \\
\text { dzony na piśmie. }\end{array}$ \\
\hline $\begin{array}{l}\text { Pracownikowi przy- } \\
\text { sługuje szereg upraw- } \\
\text { nień (urlop, zasiłek } \\
\text { chorobowy i in.). } \\
\end{array}$ & $\begin{array}{l}\text { Świadczenia przysłu- } \\
\text { gują tylko takie, jakie } \\
\text { uzgodniły strony } \\
\text { w umowie. }\end{array}$ & $\begin{array}{l}\text { Świadczenia przysłu- } \\
\text { gują tylko takie, jakie } \\
\text { uzgodniły strony } \\
\text { w umowie. }\end{array}$ & $\begin{array}{l}\text { Świadczenia przysłu- } \\
\text { gują tylko takie, jakie } \\
\text { uzgodniły strony } \\
\text { w umowie. }\end{array}$ & $\begin{array}{l}\text { Świadczenia przysługu- } \\
\text { ją tylko takie, jakie } \\
\text { uzgodniły strony } \\
\text { w kontrakcie. } \\
\end{array}$ \\
\hline \begin{tabular}{|l} 
Odszkodowanie \\
pracownika za szkodę \\
jest ograniczone do \\
wysokości \\
3 wynagrodzeń. \\
\end{tabular} & $\begin{array}{l}\text { Odszkodowanie } \\
\text { zleceniobiorcy za } \\
\text { wyrządzoną szkodę } \\
\text { może być do jej } \\
\text { wysokości. }\end{array}$ & $\begin{array}{l}\text { Wykonawca ponosi } \\
\text { pełną odpowiedzial- } \\
\text { ność za wady dzieła } \\
\text { i nie ma ograniczeń co } \\
\text { do wysokości szkody. }\end{array}$ & $\begin{array}{l}\text { Wykonawca ponosi } \\
\text { pełną odpowiedzialnoś } \\
\text { odszkodowawczą za } \\
\text { szkody. }\end{array}$ & $\begin{array}{l}\text { Menedżer ponosi pełną } \\
\text { odpowiedzialność } \\
\text { odszkodowawczą za } \\
\text { wyrządzone szkody. }\end{array}$ \\
\hline
\end{tabular}

Źródło: (Brzeziński 2017, s. 526) 
Poza wymienionymi, do korzyści pracowniczych należą jeszcze: urlopy macierzyńskie i wychowawcze, ochrona w okresie choroby czy ciąży kobiet. Ochroną objęte są również wynagrodzenia pracownicze, pod względem terminu ich wypłaty, minimalnej kwoty i niemożliwości rezygnacji przez pracownika (Kodeks pracy, art. 87-88). W przypadku zwolnień grupowych pracownicy w przeciwieństwie do pozostałych form otrzymają odprawy (Skowron-Mielnik, Wojtkowiak 2016, s. 81-84). Prowadzone badania pokazują, że warunki pracy, w jakich funkcjonują pracownicy, w większym stopniu spełniają wymogi pod względem bezpieczeństwa i higieny pracy (Brzeziński 2016, s. 358; Żaczkiewicz-Zborska, Marczuk 2008).

Zakres występowania poszczególnych form jest obiektem systematycznych badań m.in. GUS. Te przeprowadzone w 2014 roku pokazały, że praca na umowach cywilnoprawnych stanowi główny dochód w przypadku 4,4\% wszystkich pracujących osób (http://wyborcza.pl/...). Rozkład poszczególnych form zatrudnienia w tej populacji pokazano na Rysunku 1.

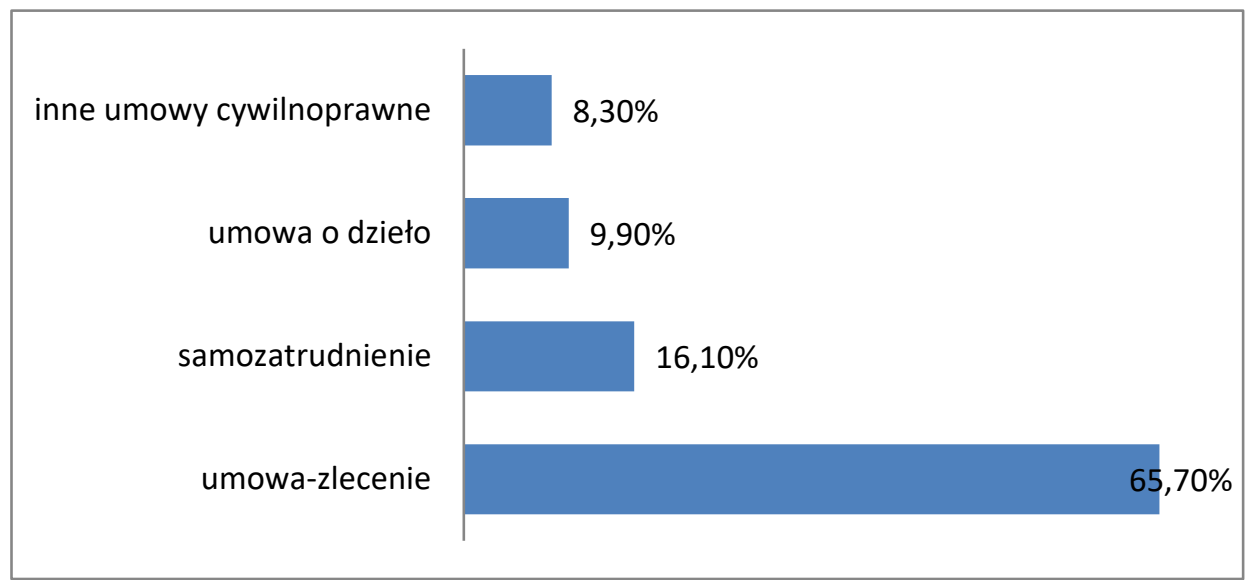

Rysunek 1. Rozkład poszczególnych form zatrudnienia wśród umów cywilnoprawnych

Źródło: Dane GUS (GUS 2016)

Przeważającą formą jest umowa-zlecenie, która dotyczy $2 / 3$ badanych. Kolejną grupę stanowią samozatrudnieni $(16,1 \%)$, a prawie co dziesiąty związany jest umową o dzieło $(9,9 \%)$, nieco mniej jest osób z innymi umowami cywilnoprawnymi $(8,3 \%)$.

Większość osób pracujących na umowach cywilnoprawnych $(80,2 \%)$ nie miała innego wyboru. Osoby z umowami-zleceniami to aż $84,3 \%$ takich sytuacji, a inne umowy cywilnoprawne to $65,4 \%$ przypadków. Samozatrudnieni to ponad połowa osób (51,3\%), dla których zakładanie firm było warunkiem koniecznym dla nawiązania współpracy. Odsetek osób z nietypowymi formami jest wyższy wśród pracujących kobiet, gdyż wynosi 4,6\%, podczas gdy w przypadku mężczyzn wynosi $4,3 \%$ pracujących. Biorąc pod uwagę grupy wiekowe, zauważyć można, że aż $13,1 \%$ osób w przedziale 15-24 lata jest tak związana z pracodawcą. Drugą grupą tak pracujących były osoby w wieku 60 lat i więcej (7\%). 
Najczęściej praca w nietypowych formach zatrudnienia wykonywana jest przez osoby z wykształceniem średnim ogólnokształcącym $(6,7 \%)$.

Inne badania GUS szacowały liczbę pracujących na umowy cywilnoprawne (http://www.wyborcza.pl/...). W latach 2013 i 2014 liczba ta kształtowała się na stałym poziomie $1,3 \mathrm{mln}$ osób, choć wcześniej miał miejsce wysoki wzrost z $0,5 \mathrm{mln}$ pracujących w 2010 roku. Należy dodać, że w branżach takich jak sprzątanie, ochrona i niektórych usługach umowy cywilnoprawne są dominującą formą zatrudnienia ludzi.

\section{Elastyczne formy zatrudnienia - wyniki badań własnych}

Badania zostały przeprowadzone w latach 2016-2017 wśród studentów studiów niestacjonarnych trzech uczelni ekonomicznych (dwie z Wrocławia i jedna z Cieszyna). Narzędziem badawczym był samodzielnie opracowany kwestionariusz pytań. Wybór respondentów został dokonany w sposób losowy, a badaniom poddano 418 osób. W przypadku 5 osób odpowiedzi w kwestionariuszu nie były kompletne i ostatecznie analizie poddano 413 ankiet. Ankietowani wskazali swoje aktualne formy zatrudnienia, które zestawiono na Rysunku 2. Dominującą formą jest umowa o pracę na czas niekreślony, która dotyczy $43,7 \%$ badanych. Druga grupa $(36,6 \%)$ to zatrudnieni na umowę o pracę na czas określony. Inne umowy o pracę to nieliczna grupa na poziomie $2,2 \%$ próby. Umowa-zlecenie to elastyczna forma zatrudnienia $\mathrm{z}$ największym udziałem $(14,1 \%)$ wśród tego typu umów. Samozatrudnieni stanowią tu $2,2 \%$ badanych, a najmniejszą grupą $(1,2 \%)$ są pracujący na podstawie umów o dzieło. Pracowników, czyli osób związanych stosunkiem pracy $\mathrm{z}$ pracodawcą, jest w próbie $82,5 \%$. Nietypowe formy zatrudnienia stanowią więc dopełnienie próby i wynoszą 17,5\%. Zauważyć należy, że część innych umów o pracę, w postaci umów na zastępstwo czy staże, można także zaliczyć do elastycznych form zatrudnienia, co ostatecznie daje prawie piątą część próby $(19,7 \%)$.

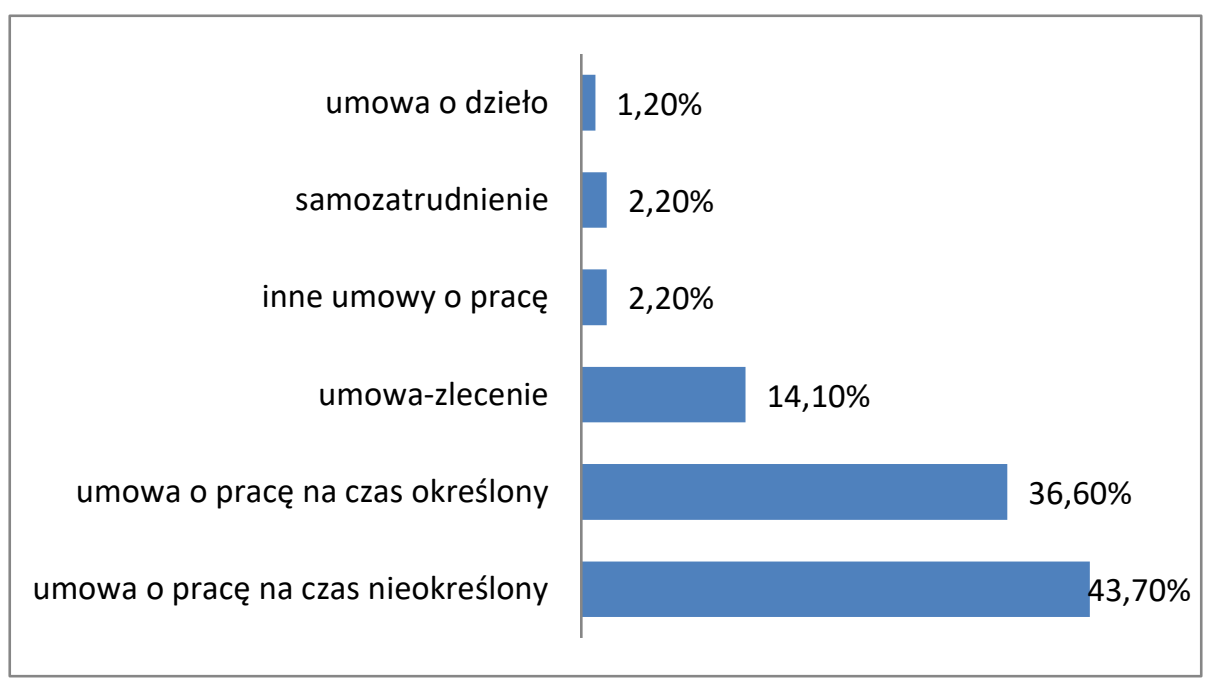

Rysunek 2. Udzial poszczególnych form zatrudnienia w próbie

Źródło: Opracowanie własne na podstawie przeprowadzonych badań 
Analiza grupy pracującej w oparciu o elastyczne formy zatrudnienia pokazała, że kobiety mają większościowy udział w wysokości 59,7\%. Stanowiska zajmowane przez elastycznych pracowników pokazano na Rysunku 3.

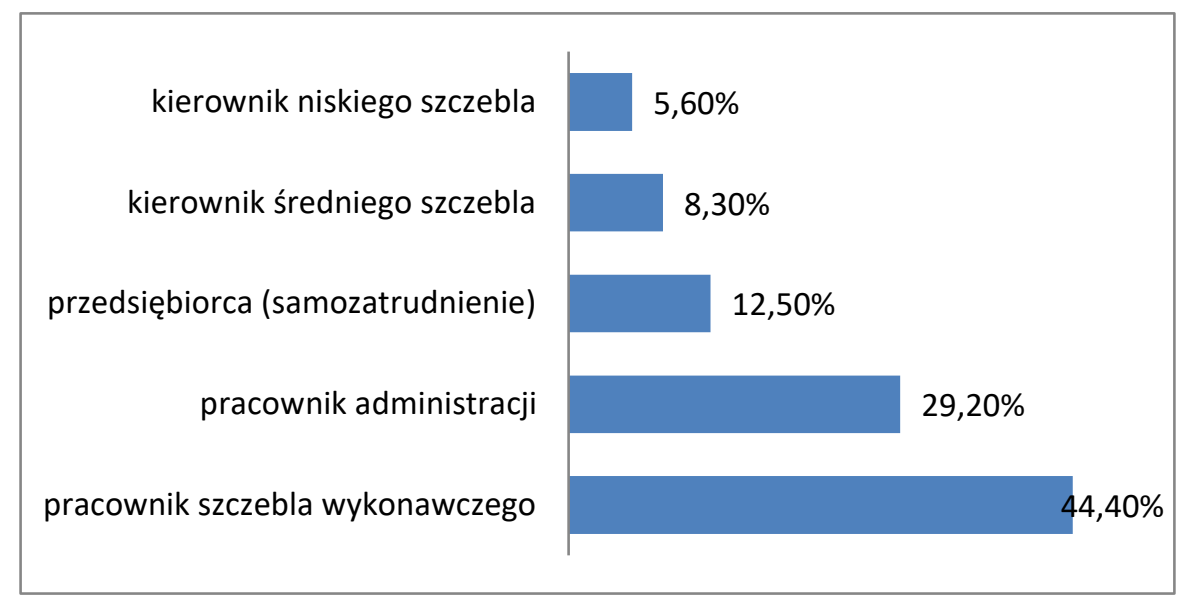

Rysunek 3. Stanowiska elastycznych pracowników wśród ankietowanych

Źródło: Opracowanie własne na podstawie przeprowadzonych badań

Największa grupa pracowników elastycznych $(44,4 \%)$ została zatrudniona na stanowiskach operacyjnych. Znaczący udział mają tu pracownicy administracyjni $(29,2 \%)$, a przedsiębiorcy jako samozatrudnieni stanowią $12,5 \%$ ankietowanych. Znaleźli się tu także i kierownicy średniego szczebla $(8,3 \%)$ i niskiego szczebla (5,3\% badanych).

Organizacje zlecające świadczenie pracy to przedsiębiorstwa różnej wielkości oraz jednostki budżetowe. Rozkład pracodawców z uwagi na wielkość przedsiębiorstw pokazano na Rysunku 4.

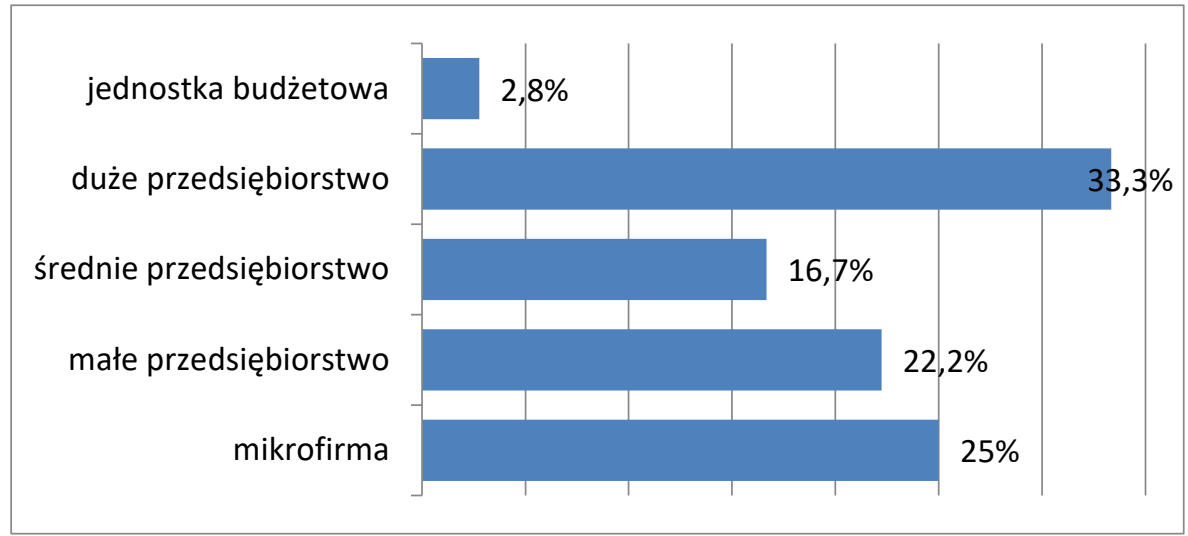

Rysunek 4. Podział pracodawców $z$ elastycznymi formami zatrudnienia ze względu na ich wielkość

Źródło: Opracowanie własne na podstawie przeprowadzonych badań 
Najliczniej reprezentowani są pracodawcy w postaci przedsiębiorstw dużych (33,3\%). Mikroprzedsiębiorstwa to czwarta część zlecających (25\%), nieco mniej jest małych przedsiębiorstw $(22,2 \%)$, zaś średnie przedsiębiorstwa to $16,7 \%$ podmiotów. Śladowy udział mają jednostki budżetowe (szkoły, wojsko, urzędy lokalne itp.) - z udziałem $2,8 \%$.

\section{Podsumowanie}

Przeprowadzone badania posłużyły do określenia form zatrudnienia w próbie studentów niestacjonarnych (418) i zakresu występowania tam elastycznych form. Ich wyniki pokazały ten rozkład, w którym umowy o pracę wiążą nieco ponad $80 \%$ ankietowanych $\mathrm{z}$ pracodawcą. Ta grupa pracowników jest zatrudniona $\mathrm{w}$ połowie na umowach o pracę na czas nieokreślony. Wysoki udział mają terminowe umowy, gdyż dotyczą co trzeciego pracownika. Elastyczne formy zatrudnienia stanowią zaś piątą część próby. To bardzo wysoki udział, który znacząco przekracza ten odsetek na krajowym rynku pracy (poniżej 5\%). Dominującą elastyczną formą jest umowa-zlecenie, która wiąże $80 \%$ elastycznych pracowników z ich pracodawcą. Wśród pracodawców korzystających z nietypowych form zatrudnienia co trzeci jest dużym przedsiębiorstwem, a co czwarty jest mikrofirmą. Obecność swoją, choć ze śladowym udziałem, mają jednostki budżetowe. Pracownicy, którym zaproponowano takie zatrudnienie, stanowią przede wszystkim $(44,4 \%)$ personel szczebla wykonawczego. Prawie jedną trzecią próby stanowią pracownicy administracyjni, ale są też menedżerowie niskiego i średniego szczebla (ok. 13\%). Wysoki udział w próbie elastycznych form tłumaczyć należy, jak się wydaje, młodym wiekiem badanych, którzy aktualne zatrudnienia mogą traktować jako przejściowe przed ukończeniem studiów, jak i jako sposób na łączenie obowiązków pracowniczych i studenckich. Istotne może być tu również ich wykształcenie, które jest na poziomie średniego, ale przede wszystkim fakt, że próba złożona wyłącznie ze studentów nie jest reprezentatywna.

\section{Literatura}

1. Bąk E. (2009), Nietypowe formy zatrudnienia na rynku pracy, C.H. Beck, Warszawa.

2. Brzeziński A. (2016), Bezpieczne i higieniczne warunki pracy w wiące celów i oczekiwań pracowniczych, „Przedsiębiorczość i Zarządzanie”, t. 14, z. 7, cz. 1, s. 347-230.

3. Brzeziński A. (2017), Formy zatrudnienia a interes pracowników, „Przedsiębiorczość i Zarządzanie", t. 18, z. 6, cz. 2, s. 517-532.

4. Culepa M., Rotkiewicz M. (2016), Umowy o pracę. Umowy na czas określony i nieokreślo$n y$, C.H. Beck, Warszawa.

5. Czapulis-Rutkowska Z. (2003), Nietypowe formy zatrudnienia i system emerytalny. Wzajemne relacje, [w:] Frieske K.W. (red.), Deregulacja polskiego rynku pracy, IPiSS, Warszawa, s. 89-91.

6. Gableta M. (2013), Człowiek i praca w zmieniajacym się przedsiębiorstwie, Wydawnictwo Akademii Ekonomicznej, Wrocław.

7. Gersdorf M. (1993), Umowa o prace, umowa o dzieło, umowa zlecenia, Wydawnictwo Prawnicze, Warszawa. 
8. Grzonka L. (2013), Alternatywne formy zatrudnienia z wzorami umów i pism, Polskie Wydawnictwo Prawnicze, Poznań.

9. GUS (2016), Pracujacy $w$ nietypowych formach zatrudnienia, file:///C:/Users/ASUS/ Downloads/notatka_nietypowe_formy_zatrudnienia_2016_01_27.pdf (dostęp: 16.08.2017).

10. http://wsb.edu.pl/container/Biblioteka\%20WSb/ksi\%C4\%85\%C5\%BCki\%20elektroniczne/ elastyczne-formy-pracy-poradnik-dla-pracownikow.pdf (dostęp: 17.06.2017).

11. http://wyborcza.pl/1,155287,21250751,gus-policzyl-liczbe-pracujacych-na-umowachcywilnoprawnych-i.html (dostęp: 17.08.2017).

12. IPiSS (2007), Elastyczne formy zatrudnienia. Poradnik dla pracowników, Wydawnictwo Wyższej Szkoły Ekonomicznej w Białymstoku, Białystok.

13. Kalinowska I., Kujszczyk B., Mańturz M., Świercz B. (2013), Elastyczne formy zatrudnienia. Informator, Wojewódzki Urząd Pracy w Warszawie Centrum Informacji i Planowania Kariery Zawodowej, Warszawa.

14. Kaniewski J. (2008), Zalety $i$ wady umów cywilnoprawnych, http://kadry.infor.pl/kadry/ inne_formy_zatrudnienia/umowy_cywilnoprawne/692794,Zalety-i-wady-umowcywilnoprawnych.html (dostęp: 17.06.2017).

15. Kodeks cywilny - Ustawa z dnia 23 kwietnia 1964 r. (Dz.U. 1964 nr 16 poz. 93, z późn. zm.).

16. Kodeks pracy - Ustawa z dnia 26 czerwca 1974 r. (Dz.U. 1974 nr 24 poz. 141, z późn. zm.)

17. Król M. (2014), Elastyczność zatrudnienia w organizacji, CeDeWu, Warszawa.

18. Kryńska E. (2007), Elastyczność zatrudnienia na polskim rynku pracy, „Polityka Społeczna", nr 11-12, s. 1-8.

19. Lundy O., Cowling A. (2000), Strategiczne zarządzanie zasobami ludzkimi, Oficyna Ekonomiczna, Kraków.

20. MRPiPS (2016), Rynek pracy w Polsce w 2015, Ministerstwo Rodziny, Pracy i Polityki Społecznej, Warszawa.

21. Organiściak-Krzykowska A., Walkowiak R., Nyklewicz N. (red.) (2014), Innowacyjne formy pracy, Uniwersytet Warmińsko-Mazurski w Olsztynie, Olsztyn.

22. Rozporządzenie Rady Ministrów z dnia 9 września 2016 r. w sprawie wysokości minimalnego wynagrodzenia za pracę w 2017 r. (Dz.U. 2016 poz. 1456).

23. Sekuła Z. (2001), Planowanie zatrudnienia, Oficyna Ekonomiczna, Kraków.

24. Skowron-Mielnik B., Wojtkowiak G. (2016), Formy zatrudnienia - analiza elastyczności pracowników, „Organizacja i Kierowanie”, nr 3(173), s. 81-98.

25. Sochańska-Kawiecka M., Morysińska A., Makowska-Belta E., Kołakowska-Seroczyńska Z., Szarfenberg R., Mering T. (2013), Elastyczne formy zatrudnienia - skutki społeczne i ekonomiczne, Obserwatorium Dolnośląskiego Rynku Pracy i Edukacji, Wrocław.

26. Trendy HR (2015), Nowy świat pracy, Deloitte University Press, http://www.deloitte.com/ content/ dam/Deloitte/pl/Documents/Reports/pl_trendy_hr_2015_kadry_nowy_swiat.pdf,2015 (dostęp: 21.06.2017).

27. Ustawa z dnia 9 lipca 2003 r. o zatrudnianiu pracowników tymczasowych (Dz.U. $2003 \mathrm{nr}$ 166 poz. 1608$)$

28. Wyrok SN (2005), Wyrok SN z 11 października 2005 r. (sygn. I PK 42/05).

29. Żaczkiewicz-Zborska K., Marczuk B. (2008), Pracujacy $w$ elastycznych formach sa bardziej narażeni na wypadki niż etatowi pracownicy, GazetaPrawna.pl, http://praca.gazetaprawna.pl/ artykuly/2574,pracujacy-w-elastycznych-formach-sa-bardziej-narazeni-na-wypadki-nizetatowi-pracownicy.html (dostęp: 17.06.2017). 


\section{FLEXIBLE FORMS OF EMPLOYMENT AND THEIR FREQUENCY RANGE}

Abstract: Article deals with the issue of flexible forms of employment, starting with the presentation of currently observed solutions in Polish law. By their comparison, the advantages and disadvantages in the point of view of employees were indicated. A study carried out among employees shows the range of use of flexible forms, among which the contract of mandate dominates.

Keywords: employer, stakeholder, human resources, flexible forms of employment 